\title{
ICT Management Information System for Rural India: A Bottomline for Indian GDP
}

\author{
*Tavishi Sharma ${ }^{1}$, Kunal Vashisth ${ }^{2}$ and Sangeeta Sharma ${ }^{3 *}$ \\ ${ }^{1}$ PGDM-FM Scholar; National Institute of Financial Management, Faridabad, India. \\ ${ }^{2}$ MS (MIS) Scholar; Management Information System, Griffiths University, Brisbane, Australia. \\ ${ }^{3}$ Assistant Professor; DAV College, MD University, Rohtak, Faridabad, India.
}

\begin{abstract}
Seventy two percent approximate populations dwelling in rural India do suffers from one or the other deprivation indicators and most of rural India remains emptied of global touch points linked to its area of economic concern. The purpose of this presentation is to address the role of 1.8 billion rural hands for uninterrupted growth of Indian economy by bringing ICT solutions within their reach. Urbanising rural India can mobilize the direction of rural masses towards productive efficiencies; evidently where whole globe will come forward for this great opportunity's radical change has taken place due to proliferation of digital technologies over the past two decades. There is a huge gap between urban and rural India in beneficial usage of ICT application. Indian masses have been well recognized by world in their knowledge economy for initiating and implementing best ICT solutions worldwide. This empirical research paper investigates the scope of implementing an economical affordable ICT solution for rural India by most efficient, economically affordable and sustainable ICT solution for globalizing rural hands. Universe of this study comprises of a cluster of twenty five villages of rural Haryana in Hisar District. It was interesting to note that even illiterate rural use some or other ICT device and they also recognize its significance yet remains handicapped of its benefits. The central argument of this work is that economical spread of optical fiber in assistance with local governance and CSR of private companies can not only play a pivotal role in reducing deprivation indicators of rural India but also open up new avenues to global economy. Furthermore, usage of affordable cloud application has been evaluated as one of the best ICT solution for rural development doctrine.
\end{abstract}

Keywords: ICT, Rural development; urbanization; rural India; cloud computing; corporate social responsibility CSR; deprivation indicators.

\section{Introduction}

Extension and advisory services are relevant to rural transformation process alongwith the right mix of policies, technologies, and market opportunities for upliftment of Indian rural. Earlier culture of policy shifts and fiscal austerity programmes have impacted much on extension services, especially on public extension, in developing countries which has been taken as a priority agenda of governance for rural India. "According to a World Bank study, a 10\% increase in mobile penetration is known to boost per capita GDP by $0.8 \%$ points in developing nations. According to a study by the Indian Council for Research on International Economic Relations (ICRIER) 6, states with a higher teledensity have grown faster than those with lower teledensity. States with $10 \%$ higher teledensity have grown $1.2 \%$ faster. For instance, Bihar could have witnessed $4 \%$ faster growth if it had enjoyed the same teledensity as Punjab. An efficient telecommunication services network facilitates smooth information flow which could result in lower transaction costs [1]. Out of seventy two percent of Indian population, almost fifty percent of Indian countryside population suffers from rural deprivation like mud made house, without no adult working man, without adult member in working age, headed by woman without adult working man, headed by women with no adult in working age, without abler body adult and landless worker. As appraised by Times of India [2], 48.5\% rural are saddled with one of seven indicators, nearly 5.4 crore rural household are landless-a main running theme of deprivation. $30 \%$ have two deprivation, $13 \%$ have three and $0.01 \%$ suffer from all three. High number deprived is landless into manual labour. Weak linkages between researchers, extension and farmers have been a major constraint in the application and uptake of new knowledge.

On contrast, out of majority share of rest twenty eight percent urban population, skill level is so high that Indians are buzz word globally especially in adopting, initiating, implementing and improving upon the ICT Solutions. If such parent players become a part of modernizing India, it will be as good as modernizing globe because 2.56 billion hands collectively can turn around the globe.

Agriculture being a vital sector with more than $70 \%$ rural areas and earns its live hood by agriculture and its related means of income. The sector faces key challenges of enhancing production in a situation of deteriorating natural resources necessary for production. The enhanced demand for agricultural products, however, also tenders an opportunity for producers to sustain and improve their livelihoods. Information and 
communication technologies (ICT) play an important role in addressing these challenges and uplifting the livelihoods of the rural poor. Still it's redesigning and upgrading the infrastructure and building capacity of rural stakeholders to be benefitted from the new ICTs is critical.

Rural population being the majority of Indian population has the potential of making India an economic superpower and a developed country. Information is critical to the social \& economic activities that comprise the development process. Telecommunications, as a means of sharing information, is not simply a connection between people, but a link in the chain of the development process itself [3].

The Government of India has launched the National Rural Livelihoods Mission (NRLM) under the Ministry of Rural Development (MoRD). The mission aims at creating efficient and effective institutional platforms of the rural poor enabling them to increase household income through sustainable livelihood enhancements and improved access to financial and selected public services. NRLM has set out with an agenda to reach out, and mobilize seventy million BPL households into self-managed Self Help Groups (SHGs) and federal institutions and support them through livelihoods collectives. In addition, the poor would be facilitated to achieve increased access to their rights, entitlements and public services, diversified risk and better social indicators of empowerment. NRLM also aims at harnessing the innate capabilities of the poor and complements them with capacities (information, knowledge, skills, tools, finance and collectivization) to deal with the rapidly changing external world.

The information technology revolution has played key role in socioeconomic development of the world and it has occupied the key place at the heart of global economic growth over the last several decades. Government of India is having an ambitious objective of transforming the citizen-government interaction at all levels to by the electronic mode (e-Governance) by 2020.Digital India - the dream project of the government and a blessing for the urban as well as rural citizens, is expected to help in connecting the dots of various projects, past and present, to bring India to a global platform. Hence, to ensure a sustainable growth and development of these rural people, the Government of India has introduced the National e- Governance Plan (NeGp) which seeks to lay the foundation with various projects, starting from the grass-root level, and providing impetus for long term e-governance within the country.

An affordable, subsidized and low cost ICT technology like Cloud Computing can certainly create a real time impact on urbanizing rural India. The Cloud allows information technology to be infused into the smallest hamlet of India and makes access to information available to the poorest of the poor to give them a better life, by empowering them with knowledge derived through the laptop or mobile phone connected to the Cloud. The Cloud has potential to drive down costs of e-Governance, education, medical care and other Government computerization initiatives. The Cloud bridges the great divide between rich urban India and poor rural India, and gives the same level playing field to all Indians.

Apart from an infrastructure challenge, the rural illiteracy which is around $40 \%$ is also coming in the way to success of implementation of ICT apps for rural. As reported by UNESCO [4], in countries where electricity remains a challenge, telephone communication facilities are also typically less than universal. For example, telephone communication devices are present in $14 \%$ and $11 \%$ of primary-level and $38 \%$ and $25 \%$ of secondary-level schools in countries like India. Affordable cost for the users and infrastructural development cost is also an issue which needs to be addressed. Cheaper IT tools/apps can prove to be a boon in transforming new India.

Summarizing, the Cloud services being scalable, agile and most economical; it permits regional language speaking literate Indians masses to make use of the information revolution and participate in governance for the future of the countryside Indian by allowing them to transact on the web in the Indian language of their choice which is a great miss as of today.

\section{Appraisal Of Literature}

As per the World Bank report, a $10 \%$ increase in mobile and broadband penetration increases the per capita GDP by $0.81 \%$ and $1.38 \%$ respectively in the developing countries. If Digital India project could help increasing the broadband penetration across India (presently-7\%) by 50\% and mobile penetration in rural India (presently-45\%) by 30\% in next 2 years, the corresponding increase in GDP could be $9 \%$ which is true for India also. Indian ex-President Dr.APJ Abdul Kalam strongly felt that the problem of urbanization could be tackled by enabling equivalent infrastructure in rural areas or building satellite towns through 3 types of connectivity proposed by Dr.APJ Abdul Kalam namely: physical, electronic and knowledge.

Salesforce.com was the first entrant in 1999, which pioneered the concept of delivering enterprise applications via a simple website. The Cloud computing is a sensation of computing technology for encompassing affordably low cost; high operational efficiency; elasticity and scalability. Business Standard (2013), had reported out of India's rural population is $857,194,567$ million; rural literate population is 368 million where 72 million claimed Internet users and 49 million active Internet users in rural India. The literature has 
traditionally concentrated on socio-economic conditions as determinants of the growth-poverty nexus. Wealth and income inequality, literacy rates, urbanization levels, mortality rates, etc. have been found to influence the degree to which growth reduces poverty [5].

Availability of connectivity up to Taluka level in India makes data connectivity a reality for rural India. This allows rural India to log on to the Hybrid cloud. An effort have also been made by some state governments, NGO's or so in this area of advantaging rural India by ICT, few examples. As Bhoomi, e-Seva, Gyandoot, Information Village, Dristi, Akaash Ganga, Shristi, Warna Wired Village, Akshya, Mahiti Sakti Kendra's per [6], "There is not only concern on how fast the "national pie expands but specifically, how the increment to the national pie is distributed". Such growth enables the poor to actively participate in and significantly benefit from economic activity [7].

Growth reduces poverty but the degree to which this occurs will be conditioned by the level of inequality. Specifically, poverty will be more responsive to growth the more even and sustain the income distribution. An important implication of this is that growth will only translate into significant poverty reduction or eradication if the distribution of income does not deteriorate [8].

The contribution of growth to poverty declines can differ across sectors for several reasons. Suryahadi [9], suggest that while the direct impact of a sector's growth on poverty is likely to be small due to its dependence on the sector's population share, its indirect effect may be much greater because of labour mobility, and the linkages between the sector's growth with growth in other sectors. In June 2014, 60\% of rural accessed internet and expected to suit up to 280 million [10]. With such a widespread usage, cost economics can be worked out using cloud computing technologies only. It is highly desirable to assess the suitability of an ICT solution having touch points such that maximum head counts can be covered. The cloud infrastructure is a composition of two or more clouds (private, community or public) that remain unique entities but are bound together by standardized or proprietary technology that enables data and application portability. Suitable policy designing and precise implementation in infrastructure, application development, and data warehousing areas collectively can transform rural governance and public life at grass root level in rural India [11].

Towards, implementation of ruralised ICT [12], highlighted that the Rural BPO programme provides subsidies to private companies and entrepreneurs in order to incentivize them to set up BPO centers in rural areas which would provide employment to rural citizens .Mckinsey [13] "The cloud," with its ability to deliver digital power at low cost and in small increments, is not only changing the profile of corporate IT departments but also helping to spawn a range of new business models by shifting the economics of "rent versus buy" tradeoffs for companies and consumers. Thus, the essence of ICT penetration has been strongly concluded by various researches as well as Government has launched certain derives for digitalizing Rural India - a step towards breaking the barriers of rural-urban divide for the overall and cohesive development of India [14],[15].

\section{Statement of Problem}

Even after 68 years of independence, there is a big gap in living standard and other necessary opportunities for improved lifestyle of rural v/s urban Indians. There are ample availability and usage of ICT solution in urban and rural masses where $70 \%$ India dwells still remain a grey area. Whenever we visit our parental village, we get a huge respect from them irrespective of deprivation they suffer and their caring attitude makes us to feel some sort of guilty as we hardly care for such nice noble souls. By discussing the problems with our village community, we felt to bring their issues forward for their prosperity. In this empirical research paper, we are making an attempt to assess the impact of penetration of cloud based ICT solution helping the development of rural masses, which, in turn can impact the bottomline of national GDP.

\section{Research Methodology}

Twenty surrounding villages of our native Hisar district of Haryana state in India have been considered as sample size including our parent village. This cluster was easily accessible and was effective for getting feedback within our own resources. Three hundred villagers have been interviewed as sample size. Interview method was used alongwith personal contact program. These primary data were collected in predesigned questionnaire and tabulated in an array for further analysis and interpretation.

Following Hypothesis were made for testing the impact of cloud computing services in countryside India.

H01: Majority of Rural India is covered and benefited by some internet excess.

H02: Rural India does recognize that affordable cloud computing apps can turn their lifestyle.

H03: Illiterate men and women are a great hurdle in understanding the usage of ICT

H04: Government and corporate have made an enough efforts in implementing low cost cloud apps for rural.

H05: Strengthening rural India can be better addressed by public and corporate sectors. 


\section{Analysis and Interpretation}

For analyzing the study scientifically, all collected data has been arranged in the form of tables. Since, there is a big gap between "Yes" and "No", percentage variation has been selected for interpretation and decision making. Table-1 illustrates the assessment of rural masses as far as usage of ICT is concerned. The Table 1 represents the responses given by the respondents on various parameters linked to usage of internet excesses in rural area.

\subsection{Discussion 1}

Table 1 exhibits that majority of rural masses are mostly connected with either TV or Radio or mobile phone. Thus, the TV, radio and mobile phones are most prevailing ICT apps valid for rural India. Hardly $10 \%$ of rural India is linked to internet excess and $22 \%$ are surveyed users of internet, mostly students and servicemen. It was surprised to note that support from rural Panchayats in providing Internet excess is hopeless; however, $33 \%$ schools have this facility. Thus, null hypothesis H01 stands rejected and rural excess to internet is a great miss. Formal computer education is around sixteen percent which cover the private coaching centers which is in contrast with $\mathrm{H} 02$ that rural masses recognize low cost cloud applications for empowering them. It was interesting to note that all rural are ready to spend on technology that gives an opportunity for their earnings. Thus the hypothesis that government and private sectors effort have shown impact on implementing low cost ICT Solution is sufficient stands rejected.

\subsection{Discussion-2}

Table-2 enumerates that the private companies have hardly any BPO centre in village are, rural are devoided from public recognized computer centre, still they strongly feel that students are interested in connectivity, multi-locational computer centre at village Mohalla can be of high impact to bring prosperity and cheaper ICT Solution like cloud apps can turn around their life in the area of agriculture, wage employment, health and education. The issue was further analysed for understanding the level of computer education in rural masses. Data collected through personal interview has been arranged in Table-3. To understand the popularity of computer knowledge, three groups were made. Group-1 comprises of males above 40 years, Group -2 is youngsters below 40 years and Group three comprised of all females.

Table 1. Responses of rural on ICT usage

\begin{tabular}{llccc}
\hline S. No. & Parameter & Responses & \\
\cline { 3 - 5 } & & Yes & No & Percent "Yes" \\
\hline 1 & Do you have TV in your house & 179 & 71 & 72 \\
2 & Possessing mobile is your lifestyle & 159 & 91 & 64 \\
3 & Do you have Laptop/Desktop facility in house & 24 & 226 & 10 \\
4 & At least one mobile is used by your family & 179 & 71 & 72 \\
5 & Do you understand internet usage through mobile app. & 56 & 194 & 22 \\
6 & Radio or TV is your favorite source of information & 228 & 22 & 91 \\
7 & Village Panchayats is equipped with Internet facility & 15 & 235 & 6 \\
8 & Do you have a landline phone & 110 & 140 & 44 \\
9 & Are you interested in technology giving an opportunity for your & 250 & 0 & 100 \\
& prosperity at 2\% of your earning? & & 0 & 250 \\
10 & Your Panchayats facilitate you with Wi-Fi. & 75 & 175 & 0 \\
12 & Is internet available in your village schools & 35 & 215 & 30 \\
\hline
\end{tabular}

Table 2 Responses of rural on ICT expansions support from urban India

\begin{tabular}{llccc}
\hline S. No & Parameter & Yes & No & \% Yes \\
\hline 1 & BPO Company's office is near to your village & 0 & 250 & 0 \\
2 & IT Company office in the vicinity of village & 0 & 250 & 0 \\
3 & There are government coaching centres in villages & 0 & 250 & 0 \\
4 & Villages do have private computer coaching facilities & 38 & 212 & 15 \\
5 & Students are willing to learn computer courses & 186 & 64 & 75 \\
6 & Computer centre at your village connects to globe & 58 & 192 & 23 \\
7 & Multi-location computer centres develop village fast & 189 & 61 & 75 \\
8 & Nominal fee is charged for Wi-Fi facility in village & 201 & 49 & 80 \\
9 & Computerizing rural will be helpful in urbanizing rural & 180 & 70 & 72 \\
10 & Presence of ICT will bring prosperity to rural & 170 & 80 & 68 \\
11 & ICT enhances education, health, agriculture in rural & 142 & 108 & 57 \\
12 & Cheaper cloud based ICT usage is acceptable to you & 189 & 61 & 76 \\
\hline
\end{tabular}


Table 3 Responses of Rural India on exposure to ICT

\begin{tabular}{clccc}
\hline Group & Parameters & Yes & No & \% Yes \\
\hline Gp-1 & Do you know the importance of computer & 115 & 135 & 9 \\
& Does any of your family member knows computer & 65 & 185 & 26 \\
& Do you all know computer basics & 26 & 224 & 10 \\
Gp-2 & Do you know basics of computer & 86 & 164 & 60 \\
& Do you understand the benefits of computer & 190 & 28 & 76 \\
& Do everyone in your family know computer & 28 & 196 \\
G--3 & Do you know computer & 54 & 110 & 21 \\
& Have you seen it & 5 & 245 & 22 \\
General & Can you operate computer & 23 & 227 & 9 \\
\hline
\end{tabular}

Table 4 Exploring user free ICT model for Rural India

\begin{tabular}{|c|c|c|c|c|}
\hline S.No. & Parameters & Yes & No & $\%$ Yes \\
\hline 1 & Panchayat sponsored free computer centre is highly desirable & 208 & 42 & 83 \\
\hline 2 & Panchayat sponsored Wi-Fi will put you at par with urban & 158 & 92 & 63 \\
\hline 3 & ICT- Infrastructure needs to be extended by govt/Panchayat & 222 & 28 & 89 \\
\hline 4 & Private server hosting will be successful in village & 167 & 83 & 67 \\
\hline 5 & Clusterised cloud usage will be a viable Solution & 198 & 52 & 79 \\
\hline 6 & Cloud companies entering in rural area will be a great success & 187 & 63 & 75 \\
\hline 7 & There is a good scope to cover group of villages/ cluster by Cloud Service Provider & 192 & 58 & 77 \\
\hline 8 & Cloud services will be fast realized by Public -Private Partnerships. & 205 & 45 & 82 \\
\hline \multirow[t]{2}{*}{9} & Cloud ICT can urbanize the rural India at fast pace & 187 & 63 & 75 \\
\hline & Average & & & 77 \\
\hline
\end{tabular}

\subsection{Discussion-3}

The Table 3 shows that computer literacy in youngsters is $34 \%$, among adults above 40 years is by $10 \%$, while in female category it worst @ 2\%. One of the reason for this is that there is only $9 \%$ computer facility available contributing a lot to this degrading level. Thus, illiteracy of rural residents is a big hurdle to make ICT impact on rural India which is not in line with null hypothesis (H03) interpreting that illiteracy among rural masses is coming on the way for penetrating ICT-apps in rural India.

\subsection{Discussion-4}

The Table 4 clearly spells that an overall of seventy seven percent rural masses feel that public, government and private sector can play a great role in urbanizing rural India by their initial contribution which is in line with H05 and in this case this hypothesis that "Strengthening rural India can be better addressed by public and corporate sectors" stands true.

\section{Conclusions}

Undoubtedly, Indians are on top in the world as IT - knowledge bank and are leaders of the most sophistic ICT-applications yet India is still backward on this front, something like a shadow below a lamp. Study exhibits that there lies a big gap in understanding, deployment and application coverage of ICT-tools among rural and urban masses. A bridging arrangement is missing for realising its absolute benefits.

Secondly, the illiteracy among Indian rural, that too of a $40 \%$ quantum is coming on the way. Its elimination is doable by making the rural educated at block level and village level. Role of Panchayats, a village civil body needs to be highly penetrating. Free internet access at specified locations in a village can prove effective in the awareness of old adults, mastering the young generation while schools can take up all students as per class level. It should be an essential part of students' curriculum by tenth standard education.

Thirdly, in urban India, there are almost all global companies in internet business. At the same time lot of fiber is spread all over India. To make internet penetration, either government or private sector or affordable technology or all together, can bring a turaround.Thus, government being committed to digitalized India and Cloud-Computing being in its place for affordability; its implementation is bound to make miracles not only for India but for the rest of the world.

Finally, role of small civic bodies like Panchayat (Rural civic body) and Block Samiti's (Group of villages' civic body) under the supervision of Taluka and District HQ can make the ICT-turnaround happen, thereby making a bridge between rural and urban India. Extension services of BPOs to rural area, a publicprivate parternerships, will strengthen it further. Penetration of ICT to rural India will not only enhance Indian GDP but also bring laurels to rest of the world. Also, ICT enabled education in rural areas can be an innovative option to fill this literacy gap and to upgrade the teaching-learning process in the rural schools for tapping the huge reserves of human resources. 


\section{Scope For Future}

As this study is self sponsored out of our emotions to our native villagers' prosperity, due to limited resources we could not cover it in total. It opens a field for studying illiterate rural, semi- literate rural, highly literate rural and students.

\section{Preamble for this Journey}

"Society comprises two classes: those who have more food than appetite, and those who have more appetite than food". Chamfort

This original research is an emotional study done under the supervision of our mother for the welfare of our villagers who always fix an eye of hope on us.

Millenniums till now have been occupied in bringing modernization, industrialization, technological advancements for the leisure of humanity resulted in rural and urban divide of society. For further advancement in world, $21^{\text {st }}$ century has to address the poverty industry all over the globe especially in developing and underdeveloped countries. There is a huge imbalance between urban and rural India and developmental issues like education, health, water, food, electricity, agriculture, poverty, unemployment and likewise. To meet this challenge at par with globe, Indian rural masses need to be taught, made available and practice the trading of information access using ICT tools and Apps.

\section{References}

[1] India: The impact of mobile phone, The Policy Paper Series - Number 9, January 2009: An econometric analysis of the impact of mobile by Prof. Rajat Kathuria, Dr Mahesh Uppal and Mamta.

(See: http://www.vodafone.com/ content/dam/Vodafone/about/public_policy/policy papers/public_policy_series_9.pdf

[2] Times of India, dated 13/7/15, p-10)

[3] Deakins, D., Mochrie, R. and Galloway, L. (2004), Rural business use of information and communications technologies (ICTs): a study of the relative impact of collective activity in rural Scotland. Strat. Change, 13: 139-150. doi:10.1002/jsc.683

[4] UNESCO INSTITUTE OF STATISTICS, (http://www.unesco.org/open-access/terms-use-ccbysa-en).

[5] Christiansen, L \& Demery, L 2007, Down to Earth: Agriculture and Poverty Reduction in Africa, ' The World Bank, Washington, D.C. Available at: http://siteresources.worldbank.org/INTPOVERTY/Resources/3356421130251872237/DownToEarth_final.pdf.

[6] Pernia, EM 2006, _Star Science: Pro Poor Programs or Pro-Poor Growth? Philippines Headline News Online, Available from: <http://www.newsflash.org/2004/02/si/si002141.htm>. [10 July 2013].

[7] Kakwani, N \& Pernia EM 2000,_What is Pro-Poor Growth?` Asian Development Review, vol.18, pp. 1-16.

[8] Ravallion, Martin (2016). Economics of poverty: History, measurement and policy. New York: Oxford University Press. ISBN 9780190212766.

[9] Suryahadi, ADS \& Sumarto, S 2009, ${ }_{=}$The Effects of Location and Sectoral Components of Economic Growth on Poverty: Evidence from Indonesia, 'Journal of Development Economics, vol. 89, no. 1, pp. 109-117.

[10] Madanmohan Rao., Internet growth, impacts and success, yourstory.com/2015/02/internet-india-2018.

[11] ICTD (Information and Communication Technologies for Development). (April 2006). Makes ICTs work for people. ICTD project news Letter, Pp. 35- 38. (www.nisg.org).

[12] Narula, S.A. \& Chopra, S. (2010) Identifying Stakeholders' Needs and Constraints Adoption of ICT Services in Rural Areas: The Case of India forthcoming for Social Responsibility Journal (Emerald Publishers).

[13] Jacques Bughin, Michael Chui and James Manyika (2013), Ten IT-enabled business trends for the decade ahead, Mckinsey Quarterly.

[14] Parekh, S. (2011, Nov.2), Library Automation in the Cloud: cybrarian (http:// www.cybrarian.in) is easy to use and easy on the budget, CR2 Technologies Ltd., Accessed on Sept. 18, 2012 from http://www.cr2.in/ pdf /whitepapers/Automation in the Cloud Cloud-based Library Automation.pdf.

[15] Parekh, S. (2011, Nov.2), Library Automation in the Cloud: cybrarian (http:// www.cybrarian.in) is easy to use and easy on the budget, CR2 Technologies Ltd., Accessed on Sept. 18, 2012 from http://www.cr2.in/pdf

/whitepapers/Automation in the Cloud Cloud-based Library Auto

\footnotetext{
Tavishi Sharma. "ICT Management Information System for Rural India: A Bottomline for Indian GDP." IOSR Journal of Economics and Finance (IOSR-JEF) 8.4 (2017): 56-61.
} 